\title{
A TEST OF THE RELATIONSHIPS AMONG PERCEPTIONS OF JUSTICE, JOB SATISFACTION, AFFECTIVE COMMITMENT AND ORGANIZATIONAL CITIZENSHIP BEHAVIOR*
}

\author{
Harif Amali Rifai
}

This study examines factors influencing organizational citizenship behavior in an organization. These factors include procedural justice, distributive justice, job satisfaction and commitment. Although previous studies have investigated commitment as antecedent of OCB, most of them did not specifically explain the type of commitment hypothesized. In terms of commitment, this study utilizes the specific type of commitment, i.e. affective commitment. The theoretical model proposes both distributive justice and procedural justice as antecedents of job satisfaction and job satisfaction has an effect on organizational citizenship behavior (OCB) through affective commitment. SEM analysis of survey data from 383 nurses who are working for private hospitals in Indonesia supports that the theoretical model has met goodness-of-fit criterions. The findings concluded that there are significant relationships between both procedural justice and distributive justice and job satisfaction. Job satisfaction has a significant impactfor developing affective commitment. The results also support that affective commitment is a significant predictor of organizational citizenship behavior.

Keywords: age; "group-value" model; moderator; noninstrumental justice; organizational commitment

\footnotetext{
* The author would like to thank Prof. Robert Waldersee (School of Business, Queensland University of Technology) for his valuable comments for this research.
} 
Gadjah Mada International Journal of Business, May-August 2005, Vol. 7, No. 2

\section{Introduction}

Relationships among work-related perceptions, attitudes, and behavior in the work setting have been an interesting theme in behavioral research. One of important reasons is that attitudes are believed to have significant impacts on human resources outcomes, for example Organizational Citizenship Behavior (OCB). OCB is a crucial factor for organizational efficiency, effectiveness, innovation, and adaptability within diverse organizations (Organ 1988). OCB has an important role 'lubricating' the social machinery of an organization that 'enables participants to cope with the otherwise awesome conditions of interdependence on each other' (Smithet al. 1983: 654). Organ (1988) also suggested that OCB as an indicator of job performance which is not only measuring the degree an employee reached in terms of quantity requirement, but also includes the spontaneous and innovative behavior. This behavior is likely to be determined by attitudes (i.e. commitment and job satisfaction) and perceptions (i.e. organizational justice), individual's commitment, which indicates the degree of individual's attachment to organization. In addition, the relationship between commitment and OCB might be affected by organizational justice and job satisfaction. Thus, the role of organizational justice in explaining relationship between job satisfaction and commitment is likely to influence OCB.
Organizational justice concept can be viewed from two perspectives: procedural justice and distributive justice. Procedural justice focuses on employees' attention 'how' decisions are processed and distributive justice refers to employees' perception on the fairness of their outcomes. People evaluate whether an outcome is appropriate, moral, or ethical, when they render a distributive judgment (Folger and Cropanzano 1998). Justification for fairness perception can be generated by existing of a frame of reference as comparing factor, what researchers term as a referent. Perception of individual in terms of decision-making process will have to do with perception of outcome fairness.

According to Greenberg (1996), perceptions of procedure are more useful for explaining attitudes toward institutions, and distributive justice perceptions have a greater influence over attitudes towards a result of decision. All the same, universality of this role not absolute and the role of justice varies according to organizational contexts and types of rewards. Treambly et al. (2000) suggested that distributive and procedural justice dimensions must be present if attitudes toward rewards are to be properly understood, and perceptions of organizational justice and compensation satisfaction can independently influence attitudes toward the organization. Justice perceptions may have consequences on other elements that can affect organization's performance, such as job satisfaction and organizational commitment. 
Rifai-A Test of the Relationships among Perceptions of Justice, Job Satisfaction, ...

Figure 1. Proposed Conceptual Model

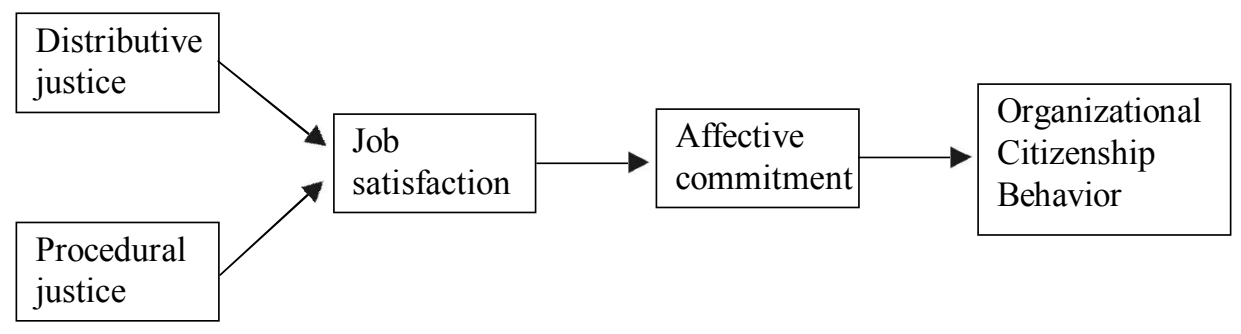

Source: Developed for this research

This study aims to test a model which identifies the impact of justice perceptions on job satisfaction and the effects of that job satisfaction on affective commitment and the impact of that commitment on individual OCB. To address the purpose of this study, a theoretical framework needs to be established.

Further, the theoretical model predicts that affective commitment is an important predictor of $\mathrm{OCB}$, affective commitment as result of job satisfaction, and perceptions of justice are antecedents of job satisfaction. The premise of the model is grounded in several thoughts. Firstly, the notions of job satisfaction as an antecedent of commitment have received considerable empirical supports (Mowday et al. 1982; Price and Mueller 1986). Nevertheless, the notions did not clearly reveal which type of commitment was hypothesized (e.g., affective commitment) as function of job satisfaction. Secondly, Schappe (1998) has showed that organizational commitment emerged as a significant predictor on organizational citizenship be- havior when job satisfaction, justice, and commitment were considered simultaneously. Finally, Williams and Anderson (1991) suggested that organizational commitment should be included when studying effects of job satisfaction on $\mathrm{OCB}$, given the potentially spurious significant findings of previous research that has considered only one of the two variables. In general, the developing body of literature leads this research to a common theme as illustrated at Figure 1.

\section{Theoretical Framework and Hypotheses Development}

\section{The Effect of procedural justice on job satisfaction}

'The experience of procedural justice (or procedural justice) is a profound feature of social life, and one that is worthy of study in its own right' (Lind and Tyler 1988: 93). The term of procedural justice has developed from allocation preference theory (Greenberg 1987). This theory proposes a general model of allocation 
Gadjah Mada International Journal of Business, May-August 2005, Vol. 7, No. 2

behavior or procedures where the application of the theory almost exclusively to procedural decision rather than its content. The processes of how employee outcomes are determined rather than what outcomes received can be seen as an underpinning of the procedural justice. In a sense, the procedure that is used to determined employee outcomes might be more important than actual outcomes itself(Folger and Martin 1989; Martin and Bennett 1996). For instance, employee perceptions of performance appraisal might be determined by an evaluation system's perceived fairness, regardless the appraisal results were positive or negative. In this case, the procedures seem more important than the end results; a favorable outcome does not necessarily bring with it recipient support. Moreover, recipients are more likely to support an unfavorable outcome when they perceive the decision-making procedures to be fair.

According to Agho et al. (1993), few procedural factors were likely to be associated with job satisfaction. These factors include freedom to make jobrelated decisions, to make contributions to the organizational work process and share beliefs to organizational processes. Employees are less satisfied with their job when they do not have the information about decision-making procedures adequately, and receive incompatible requests from their supervisor. Therefore, procedural justice contributes a significant effect on job satisfaction.
Folder and Konovsky(1989) stated that procedural justice factors are interpretable as indicating employees' interest in forms of respect. Respect for person is shown by treating the employees in ways that can be seen to be justified. People will portray a negative attitude and/or behavior when an explanation for the decision making procedure is inadequate in their perception.

The reward decision-making procedures might have a substantial impact on organization. The reward system is one of the ways how organization motivates employees, due to the satisfaction gained by receiving rewards as a consequence of exchange process consideration such as between salary and labor, or effort. Reward systems are an explicit statement of the organization's value and beliefs and have implications on the decision-making procedures in an organization. As it turned out, it is important to be considered how procedural justice to enhance positive evaluation of the rewards which finally leads to increase job satisfaction. Therefore, it can be said that the impact of procedural justice on the personal-level evaluations may be associated with positive emotional responses that reflects how individuals react to decision-making process. Lind and Tyler (1988) contended that satisfaction is one of the significant impacts of procedural fairness.

Several research have also noted that procedural justice may provide a better explanation for employee satis- 
Rifai-A Test of the Relationships among Perceptions of Justice, Job Satisfaction, ...

faction and loyal behavior than distributive justice (e.g., Folger and Konovsky 1989; Scarpello and Jones 1996; Sweeney and McFarlin 1997). Yoon (1996) found the effect of procedural justice and status equity is to enhance job satisfaction more than distributive justice. He contended that Asian societies are more concerned with social harmony, relational norms, and collective values compared with Western societies. Collectively-oriented societies prefer the equality principle and need-based distribution rule of rewards, while individualistically-oriented societies prefer the contribution-based equity principle. In the case of Asian context, 'they value in group membership more than tangible reward; an individual's inference of the whether the employment organization treats him or her as deserved in group member is often based on procedural justice treatments in the group or organization' (Yoon 1996: 125). To further explore relationship between procedural justice and job satisfaction, the research presents the following hypothesis:

Hypothesis 1: The higher the level of proceduraljustice perceived by employees, the higher the level of their satisfaction with the job.

The Effect of Distributive on Job Satisfaction

Distributive justice refers to perceived fairness of distribution outcomes that includes the conditions and goods that affect individual well-being (Deutsch 1985). According to Greenberg (1987), distributive justice is a concept focused on how individuals respond to unfair treatment of organization, or unfair distribution of rewards and resources. Jasso (1980) claimed that distributive justice is an outgrowth of sociological theories because the theory explained thenature of social comparison.

The logic of distributive justice theory derives from a functional relationship between outcomes (rewards) and contributions of input compared with some standards of comparison. The degree to which a distribution is judged to be fair or unfair will depend on the valuation of these comparisons. The sources of comparison may be other people, a generalized other or ones' own past rewards. Perception that regards the fairness of distribution is a cognitive decision, thus, it may lead to emotional outcomes or emotional behavior. Homans (1961) also noted a similar idea as the following citation:

'The more to a man's disadvantage the rule of distributive justice fails of realization, the more likely he is to display the emotional behavior we call anger. Distributive justice may, of course, fail in the other direction, to the man's advantage rather than to this his advantage, and then he may feel guilty rather than angry' (pp: 75-76).

In organizational settings, distributive justice variable may predict individual-level of outcome such as job satisfaction. Employees' percep- 
tions of fairness to their payment may lead to individual well being when the distribution of rewards is fair; consequently it will able to increase feeling of satisfaction. Contemporary studies noted that employees have a tendency to display feeling of dissatisfaction as they perceive an unfair content of rewards (Cropanzano and Greenberg 1997).

Folger and Konovsky (1989) and McFarlin and Sweeney (1992) who investigated employees' reaction to organizational pay system found distributive justice to be a stronger predictor of pay satisfaction than procedural justice. Employees who perceive they are being fairly treated with regard to a pay raise are not only satisfied with their raise but also demonstrated an increase in their commitment. They also found the strongest relationships were those between distributive justice and pay satisfaction, and procedural justice and organizational commitment.

Fields et al. (2000) reported that both distributive and procedural justice have effect on job satisfaction and evaluation of supervision. Their research also supported that procedural justice as having a larger effect on evaluation of supervision; and distributive justice has a larger effect on intent to stay and job satisfaction.

Lawler (1971) demonstrated that the distribution of organizational rewards, including pay, promotion, status, performance evaluations, and job tenure, have significant effects on several outcomes, namely job satisfaction, quality of work life, and organizational effectiveness. Folger and Konovsky (1989) also showed similar findings that pay rise and job satisfaction significantly related to the perception of distributive justice.

Tyler et al. (1985) reported that both procedural and distributive justice contribute significantly to variance in outcome satisfaction. Even though both of justice contribute to variance in satisfaction, but contribution of distributive justice is nearly twice that of procedural justice. It can be seen that there is a statistical difference of magnitude between distributive justice and procedural justice. However, both types of justice make a significant contribution to explanation of outcome satisfaction.

In general, the body of literature supports the notions that both distributive justice and procedural justice may lead to feeling of satisfaction or dissatisfaction. Distributive justice may be a more important predictor of personal outcomes or personal-level evaluations for the individuals who tend to consider the content of outcome. The distributive justice tends to explain specific attitudes about particular outcomes in question, while impact of procedural justice concerns attitude towards the institution (Greenberg 1990). Therefore, justice perception of the outcomes leads to feeling satisfaction. Thus, the research proposes following hypothesis:

Hypothesis 2: The higher the level of distributivejustice perceived by employees, 
Rifai-A Test of the Relationships among Perceptions of Justice, Job Satisfaction, ...

the higher the level of their satisfaction with the job.

\section{The Effect of Job Satisfaction on Affective Commitment}

Angle and Perry (1981) and William and Hazer (1986) suggested that job satisfaction is a determinant of commitment which is based on an exchange of resources between individual and organization. Lum et al. (1998) contended that despite the major focus of studies have explored antecedents of commitment from various categories (e.g. personal characteristics, experience, organizational factors, and role-related factors), still no clear relations can be hypothesized.

The development of commitment may involve the vague reciprocal relationship of attitudes and behavior over time. Porter et al. (1974) noted that 'organizational commitment may represent a related but more global evaluative linkage between the employee and organization that includes job satisfaction among its specific components' (p. 604). The process through which commitment is developed may include 'self-reinforcing cycles' of attitudes and behaviors. These attitudes and behaviors would evolve on job and over time strengthen employee commitment to the organization (Porter et al. 1974).

DeCotiis and Summers (1987) expressed a similar view that job satisfaction as determinant of commitment. A possible explanation is that while satisfaction and commitment are each a function of the correspondence between individual expectations (of their organizations) and organizational reality, satisfaction is a more immediate consequence of one's perceptions of correspondence. Thus, commitment can reduce the dysfunctional effect of shortterm idiosyncratic behavior on the part of the organization towards an individual employee (DeCotiis and Summers 1987). For instance, an employee who has a high affective commitment is unlikely to show a negative reaction in regard to pay rise which they receive to be inadequate.

Although developing concepts of commitment haveidentified three forms of commitment (affective, normative, and continuance commitment), affective commitment has gained much attention in the behavioral research(Allen and Meyer 1990). In addition, this kind of commitment is based on psychological attachment, therefore, it is more appropriate included to investigate an integrated model which contains justice, satisfaction, and organizational citizenship behavior.

Affective commitment refers to emotional attachment to, identification with, and involvement in the organization (Meyer and Allen 1987). Developing of affective commitment in organization might be influenced by to what extent the organization is able to satisfy employees' needs, to meet their expectations, and to allow them to achieve their goals (Meyer et al. 1993). Affective commitment develops on the 
Gadjah Mada International Journal of Business, May-August 2005, Vol. 7, No. 2

basis of psychologically rewarding experiences. Meta analyses of Mathieu and Zajac (1990) found that affective commitment is likely to be low among employees who are unsure about what is expected of them or who are expected to behave in ways that seem incompatible with organizations' values. It can be argued that emotional attachment develops through positive effect resulting from supportive experience associates with employee's environment, including organization. Experience that employees find particularly satisfying are likely to increase affective commitment toward the organization; those experiences that are not satisfying might reduce feeling of attachment.

Employees with weak affective commitment tend to experience stress and feel displeasure when organizational changes take place (Begley and Czajka 1993). It can be argued that individuals with strong affective commitment appear to be buffer against the impact of stress and displeasure. If the employee feels unhappy because of changing conditions in the organization, the workers with strong affective commitment would be able to strengthen their attitude toward organizational outcome (e.g., reduce intention to quit or increasing $\mathrm{OCB}$ ).

Affective commitment may also develop on the basis of retrospective rationality or justification processes. According to retrospective rationality view of commitment, employees who had greater freedom to accept their job (more volition) demonstrated significantly stronger affective commitment to the organization they chose than did those with less freedom. Therefore, the increase autonomy should facilitate higher level of job satisfaction. The quality of the chosen jobs was higher for those who made their choice freely than for those who were more constrained by other factors (Meyer et al. 1993).

Wanous et al. (1992) supported that employee expectations moderate the extent to which individual's experiences will be associated with affective commitment. Meta-analyses in terms of relationship between employee expectations and affective commitment showed average correlation of .39 (Wanous et al. 1992). Therefore, job satisfaction that implies conformity to a person's expectation and his or her experiences is significant in building the affective commitment. Organization can increase job satisfaction by providing accurate information that reflects real conditions of the jobs (Wanous et al. 1992), in turn, leads to a high affective commitment. The review of literature above support to develop the following hypothesis:

Hypothesis 3: The higher the level of job satisfaction perceived by employees, the higher the level of employees' affective commitment 
Rifai-A Test of the Relationships among Perceptions of Justice, Job Satisfaction, ...

The Effect of Affective

\section{Commitment on Organizational Citizenship Behavior (OCB)}

Predictions about the influence of organizational commitment on OCB still show a lack of consistency of the findings. O'Reilly and Chatman (1986) examined relationship between the underlying dimensions of commitment (compliance, identification, and internalization) and self-reporting OCB. The study found that the internalization and identification, as a component of affective commitment, were significant predictors of self-report OCB. It can be said that affective commitment is more likely to be related to OCB.

Meanwhile, William and Anderson (1991) proposed that job satisfaction and organizational commitment is related to OCB. Their study identified two broad categories of $\mathrm{OCB}$, which they labeled (a) OCBO - behavior that benefit the organization in general and (b) OCBI- behavior that immediately benefit specific individuals and indirectly contribute to the organization. The findings supported those cognitive components of satisfaction (job cognition intrinsic, job cognition extrinsic and positive arousal) are significantly correlated with both OCBI and OCBO. In addition, the increment in $R^{2}$ associated with the cognitive set was significant for both OCBI and OCBO. However, the study failed to find correlations between commitment and these OCBs.
Organizational commitment is believed to be an attitudinal variable that is likely to influence citizenship behavior. Organizational commitment can be considered as 'the relative strength of an individual's identification with and involvement in an organization' (Mowdayet al. 1979: 226). Wiener (1982) noted that commitment might operate as a force that enables to maintain 'behavioral direction' when the individuals' expectations are not met, or inequity occurs. OCB reflects behavior in the workplace that is not directly related to formal organizational reward(Organ 1987). Linking between commitment and OCB can be seen when the expectations of formal reward are not completely met, yet the employees with strong commitment remain to show innovative and spontaneous behavior which are beyond their job description.

Affective commitment can be said the strength of an individual's attachment to an organization (Meyer and Allen 1984). Dyne and Ang (1998) explained that attachment typically develops out of frequent and repeated exchanges that make ongoing relationship possible. Affective commitment to organizations is influenced by workers' perceptions of the support they received from their organizations. When the individuals feel they are treated well by their organization, they reciprocate and exceed the minimum requirements of their job by helping others as well as the organization (Konovsky and Pugh 1994; Organ 
Gadjah Mada International Journal of Business, May-August 2005, Vol. 7, No. 2

1988). Thus, in this sense of psychological attachment, affective commitment can be viewed as an antecedent of OCB. Shore and Wayne (1993) noted that there is a relationship between affective commitment and supervisor rating of OCB. A similar finding is also reported by Organ and Ryan (1995).

Relationship between organizational commitment and OCB has been also documented by Meyer et al. (2000). Their research found that among three-dimension of commitment (i.e., affective, normative, and continuance), affective commitment has the strongest positive correlation with the citizenship behavior, followed by normative commitment. However, continuance commitment is unrelated to that behavior. According to Morisson (1994), these different patterns of the research finding are probably caused by the boundary between extra role and in-role behavior toward employee's attitude which is often unclear.

Bolon (1997) attempted to exam relationship between three forms of organizational commitment and citizenship behavior. The study found that there is a significant and positive relationship between affective commitment and OCBI (a specific individual as the target) using supervisor-rating and coworker-rating. Employees' emotional attachment to, identification with, and involvement in, the organization may contribute the achievement of organizational objectives. An individual is eager to assists other with organiza- tionally relevant tasks or problems because that action is perceived as contributing to or advancing organizational goals and values. O'Reilly and Chatman (1986) noted that there are positive associations between identification, and internalization and OCB. Thus, affective commitment can be said positively correlate to OCB.

O'Reilly and Chatman (1986) demonstrated that individual's psychological attachment based on their identification -involvement referred to a desire for affiliation - was found to be a significant predictor of extra-role behavior (OCB). By referring to Meyer and Allens' (1984) definition, both identification and involvement are bases of psychological dimensions of affective commitment. Allen and Meyer (1990) argued that 'employees' willingness to contribute to organizational effectiveness will be influenced by the nature of the commitment they experience'(p.73). Employees' efforts to behave on behalf of the organization are likely to be determined by affective commitment rather than continuance commitment, or normative commitment. This argument can be linked to the nature of affective commitment as pertinent to emotional attachment, so that, feelings of responsibility to increase behaviors that support organizational objectives are created. Therefore, the research proposes:

Hypothesis 4: The higher the level of affective commitment perceived by employees, the higher thelevel of organizational citizenshipbehavior. 
Rifai-A Test of the Relationships among Perceptions of Justice, Job Satisfaction, ...

\section{Research Method}

\section{Sample and Data Collection}

Data were obtained from full-time nurses of private hospitals in West Sumatera and Riau Province in Indonesia. Survey packet consisted of the demographic characteristics of the respondents and multiple-item (positively and negatively worded) survey instruments. A mail survey with nonprobability sampling method was administered to all four hundreds and fifty nurses across the eight hospitals. The questionnaires were sent along with a cover letter explaining the importance of the research. They were addressed to personnel managers of the selected hospitals to be distributed to the respondents by supports of Chief Nurse Executive. Participation was voluntary and responses were treated with confidentiality. Data were collected over a 3-month period. Each respondent received a personalize envelope, and completed questionnaires were returned sealed in envelops provided by the researcher to a specially marked box in hospital's human resource department. The result of survey produced a usable response rate of 85.11 percent $(\mathrm{N}=383)$.

\section{Measurement}

Measurements of distributive justice, procedural justice, job satisfaction, affective commitment and organizational citizenship behavior (OCB) were adopted and developed on the basis of established existing variables from previous studies. All variables were measured with 5-point Likert type scaled.

The distributive justice measures consisting of four items were adapted from Yoon and Thye (2002). The sample items are 'Compared to other employees in this hospital, my work reward is proper in view of my training and education'. The procedural justice scale consisting of four items were also adopted from Yoon and Thye (2000). The measures reflected instruments of behavioral research in the hospital setting. Both distributive justice and procedural justice measures with the anchors to strongly disagree (1) and to strongly agree (5). Job satisfaction scale was measured by four items scale which was developed by Brayfield and Rothe (1951). These items were intended to measure a global index of satisfaction of the worker in the workplace. The sample items are 'I am contented with my job itself' and 'I like my current job', with the anchors very dissatisfied (1) and very satisfied (5). An eight-items of affective commitment scale was adapted from Alen and Meyer (1990). Affective commitment refers to emotional attachment to, identification with, and involvement in, and enjoys membership in, the organization (Allen and Meyer 1990). The sample item of commitment is: (a) 'I would be very happy to spend the rest of my career with this hospital', with anchors strongly disagree (1) and strongly agree (5). Organizational citizenship behavior (OCB) was measured by a 4-item scale were 
Gadjah Mada International Journal of Business, May-August 2005, Vol. 7, No. 2

derived from the original scale (16 items). These items were adopted from the original scale (16 items) developed by Smith, Organ and Near (1983). A 4-item scale of OCB was considered in this study due to unidimensionality reason of this measure.

\section{Analysis}

Data analysis was conducted in two stages. Firstly, checking for data entry includes validity and reliability of variables, identification outliers and normality of the data. Unidimensionality of measures was assessed by Principal Component Analysis (PCA). Secondly, testing of a fit model was conducted by using Structural Equation Modeling (SEM). AMOS 4.0 computer program was utilized to run data from questionnaires. 'Goodness-of-fit' model were assessed by three criteria: absolute fit measure, incremental fit measure and parsimonious fit measure (Table 2).

\section{Results}

\section{Demography of the Sample}

The majority of the sample were female ( 86.4 percent) with a mean age of 29.3 years (ranging between 20 to 69 years). Seventy-six per cent were under 30 years of age, 15.1 percent were between 30 and 40 years of age, 6.8 percent were between 40 and 50 years of age, and the remaining 2.1 percent were above 50 years of age. Slightly more than half (53.3 percent) reported being married or cohabiting. A fairly large proportion of the sample (56.8 percent) did not have children. A greater number of nurses in current sample have one child (23.4 percent). The education level reported was 29.9 percent at the baccalaureate in nursing level, 67.2 percent at diploma level, and 3 percent at bachelor degree nurses level. The majority of educational level of nurses was diploma level. The average number of years as nurse in this sample was 8.3 years, which had the largest proportion (42.6 percent) ranging between one to five years. Meanwhile, the average employment with the hospital was 6.6 years with the largest proportion (57.4 percent) ranging between one to five years. Most of the nurses (57.4 percent) received low level income, that is less than IDR750,000.

\section{Psychometric Properties of the Scales}

Each measurement variable was tested using principal factor analysis (PCA) to assess whether the items represent a single underlying construct. Unidimensionality of the construct can be demonstrated by extracting a single component with an Eigen value greater than 1. Furthermore, items with factor loading 0.50 or greater are considered practically significant (Hair et al. 1998). Results of PCA asserted that not all measures indicated a single underlying construct. The construct of affective commitment, and OCB provided more than one factor. Therefore sev- 
Rifai-A Test of the Relationships among Perceptions of Justice, Job Satisfaction, ...

Table 1. Correlations, Alpha, Mean, and Standard Deviation of Job Satisfaction, Distributive Justice, Procedural justice, Affective Commitment, and $\mathrm{OCB}$

\begin{tabular}{|c|c|c|c|c|c|c|c|c|c|c|}
\hline \multicolumn{2}{|c|}{ Variables } & \multirow{2}{*}{$\frac{1}{1.00}$} & \multirow[t]{2}{*}{2} & \multirow[t]{2}{*}{3} & \multirow[t]{2}{*}{4} & \multirow[t]{2}{*}{5} & \multirow{2}{*}{$\frac{\text { Alpha }}{.69}$} & \multirow{2}{*}{$\frac{\text { Mean }}{3.61}$} & \multirow{2}{*}{$\frac{\text { S.D }}{.58}$} & \multirow{2}{*}{$\frac{\mathbf{N}}{383}$} \\
\hline JS & (1) & & & & & & & & & \\
\hline DJ & (2) & $.228(* *)$ & 1.00 & & & & .85 & 2.77 & .89 & 383 \\
\hline PJ & (3) & $.239(* *)$ & $.565(* *)$ & 1.00 & & & .91 & 2.69 & .95 & 383 \\
\hline $\mathrm{AC}$ & (4) & $.342(* *)$ & .053 & $.124(*)$ & 1.00 & & .70 & 3.32 & .65 & 383 \\
\hline $\mathrm{OCl}$ & $5)^{\wedge}$ & $.121\left(^{*}\right)$ & $.251(* *)$ & .101 & $.233(* *)$ & 1.00 & .65 & .636 & .21 & 383 \\
\hline
\end{tabular}

Note: ** significant at level $\mathrm{p}<0.01$, *significant at level $\mathrm{p}<0.005 ; \wedge^{\wedge} \mathrm{OCB}$ was transformed due to normality problem. Other constructs were normally distributed.

eral items were dropped from those instruments. The psychometric properties of scales are reported in Table 1.

The reliability of composite variables is also presented in Table 1 using cronbach alpha. Hair et al. (1998) suggested that usual lower limit for Cronbach alpha is .70, but in exploratory research (as is being conducted here) this limit may decrease to .6. The larger reliability of the construct will indicate the smaller the error. The reliability implies high intercorrelation within the construct. Lack of high reliability is to a great extent accounted for when using structural equation modeling (Bollen and Lennox 1991). Cronbach alpha of job satisfaction, procedural justice, distributive justice, affective commitment, and OCB is .69, $.85, .91, .70$, and .65 , respectively.
The estimated correlation matrix for the constructs can be seen in Table 1 and shows that estimated correlations among constructs do not indicate multicollinearity problem of lack of discriminant validity.

\section{Test of the Structural Model}

The subsequent analysis for testing overall model and developed hypotheses utilized structural equation modeling by operating AMOS program. The objective of the test is to assess the goodness of fit between the model and the sample data (Byrne 2001). Hair et al (1998) recommended threetypes of goodness-of-fit measures, namely absolute fit measures, incremental fit measures, and parsimonious fit measures (Table 2). 
Gadjah Mada International Journal of Business, May-August 2005, Vol. 7, No. 2

Test of statistic for parameter estimates is assessed by critical ratio (c.r.). It represents the parameter estimate divided by its standard error. Critical ratio values which are larger than 1.96 prove the path coefficient to be statistically significant at level $p<.05$. The chi-square of the theoretical model was 18.601 with 5 degree of freedom (df). It was statistically significant at level $\mathrm{p}<.001$. A nonsignificant chisquare shows support for believe that the differences of the predicted and actual matrices are not significant and it indicates an acceptable fit (Hair et al. 1998). Therefore a nonsignificant chisquare is desired.

Statistical significance level of chi-square indicates the probability that the difference is due to solely to sampling variation. However, 'statistical nonsignificance does not assure the researcher that another model would not fit as well or better' (Hair et al. 1998, p. 654). In addition, the chisquare values are sensitive on sample size. If the sample size becomes large enough, significant differences will be found for specified model. Using the $\chi^{2}$ index represents little guidance in determining to extent to which the model does not fit (Byrne 2001). For this reason other fit indices $\left(\chi^{2} / \mathrm{df} ; \mathrm{GFI}\right.$; RMSEA; AGFI; TLI;NFI; CFI; RMR), that may minimize the effect of sample size, are utilized to assess the fit model. The result of the structural equations test of the composite variables indi-

Table 2. Evaluation of SEM with Goodness-of-fit Measures

\begin{tabular}{|c|c|c|}
\hline Types of Measures & Goodness-of-fit Measures & $\begin{array}{c}\text { Level } \\
\text { of Acceptable }\end{array}$ \\
\hline \multirow[t]{3}{*}{ Absolute Fit Measure } & Goodness-of-fit index (GFI) & Greater than .90 \\
\hline & $\begin{array}{l}\text { Root mean square error of } \\
\text { approximation (RMSEA) }\end{array}$ & Under .08 \\
\hline & $\begin{array}{l}\text { Adjusted goodness-of-fit index } \\
\text { (AGFI) }\end{array}$ & Greater than .90 \\
\hline \multirow[t]{3}{*}{ Incremental Fit Measure } & Tucker-Lewis index (TLI) & Greater than .90 \\
\hline & Normed fit index (NFI) & Greater than .90 \\
\hline & Comparative Fit Index & Greater than .90 \\
\hline Parsimonious Fit Measure & Normed-chi-square $\left(\mathrm{c}^{2} / d f\right)$ & $\begin{array}{l}\text { Lower limit } 1.0 \\
\text { Upper limit } 2.0 / 3.0 \\
\text { or } 5.0\end{array}$ \\
\hline
\end{tabular}

Source: Adopted from Tabachnick and Fidell (2001); Hair et al. (1998); Byrne (2001) 
Rifai-A Test of the Relationships among Perceptions of Justice, Job Satisfaction, ...

Table 3. Structural Model Equation Results

\begin{tabular}{|c|c|c|c|}
\hline Hypothesis & Path & $\begin{array}{c}\text { Standardize } \\
\text { Regression } \\
\text { Weight }\end{array}$ & $\begin{array}{c}\text { Critical } \\
\text { Value }\end{array}$ \\
\hline Hypothesis1 & Procedural justice $\rightarrow$ Job satisfaction & $0.14 *$ & 2.15 \\
\hline Hypothesis2 & Distributive justice $\rightarrow$ Job satisfaction & $0.16^{*}$ & 2.54 \\
\hline Hypothesis3 & Job satisfaction $\rightarrow$ Affective commitment & $0.34 * *$ & 6.67 \\
\hline Hypothesis4 & Affective commitment $\rightarrow$ OCB & $0.16^{*}$ & 3.08 \\
\hline
\end{tabular}

Note: All indexes are above the cutoffs for goodness of fit criteria. ${ }^{*} \mathrm{p}<.05$. ${ }^{* *} \mathrm{p}<.01$. $\mathrm{N}=338$.

cated that the theoretical model achieved an acceptable fit to the data, $\left(\chi^{2} / \mathrm{df}=3.72 ; \mathrm{GFI}=.98 ;\right.$ RMSEA $=$ $.09 ; \mathrm{AGFI}=.94 ; \mathrm{TLI}=.87 ; \mathrm{NFI}=.92$; $\mathrm{CFI}=.94 ; \mathrm{RMR}=.027)$, which is above the cutoffs for good fit. Therefore, the model indicates a good predictor of this sample.

The results support the hypothesis 1 that the higher the level of procedural justice perceived by employees, the higher the level of their satisfaction with the job $\left(\beta=.14^{*}\right.$; significant at level $\rho \leq .05)$. The empirical findings also support hypothesis 2 ; the higher the level of distributive justice perceived by employees, the higher the level of their satisfaction with the job $\left(\beta=.16^{*}\right.$; significant at level $\rho \leq$ $.05)$. Similarly, the test shows a significant support for hypothesis 3 ; the higher the level of job satisfaction perceived by employees, the higher the level of employees' affective commitment $\left(\beta=.34^{* *}\right.$; significant at level $\rho \leq$ $.01)$. Subsequently, this study also finds support for hypothesis 4; the higher the level of affective commitment perceived by employees, the higher the level of organizational citizenship behavior $\left(\beta=.16^{*}\right.$; significant at level $\rho \leq$ $.05)$. Therefore, the statistical findings of the study demonstrate empirical support for all hypotheses.

\section{Discussion}

The part of the model supports that both distributive justice and procedural justice as being significant antecedents of job satisfaction. The predicted influence of distributive justice on job satisfaction supports the empirical evidence from previous study (Alexander and Ruderman 1987; Cropanzano and Greenberg 1997; Folger and Konovsky 1989). In terms of distributive justice, individuals' reactions to their organization are more determined by the amount and form of compensation they received $\left(\beta=0.16^{*}\right.$, significant at $p \leq 0.05$ ). The findings of the present study showed that job satisfaction in the workplace is more de- 
Gadjah Mada International Journal of Business, May-August 2005, Vol. 7, No. 2

termined by perception of distributive justice. Employees' perceptions of a just allocation of resources are likely to be influenced by how individuals assess their outcomes (rewards) and their contributions of inputs which as compared to some comparison standards, as explained in equity theory (Adam 1965).

Perceptions of distributive justice are related to cognition decision which stimulates exhibition of emotional positive (e.g. satisfaction) or negative (e.g. dissatisfaction) outcomes. Feelings of satisfaction towards employees' outcomes are likely to occur when there is a belief that the rewards received are equitable and proportional relative to others (Martin 1981). In other words, employees feel satisfied with outcomes when they believe that content of rewards they perceive to be fair is higher than the contents of rewards they perceive to be unfair (Cropanzano and Greenberg 1997). Therefore, employees who perceive fairness in terms of reward allocation are likely to have increased job satisfaction.

The model demonstrated that the procedural justice contributes effect on job satisfaction. Although distributive justice related to the amount of reward they receive, perceived unfair of the reward decision-making procedure will also influence job satisfaction. In other words, impact of procedural justice also contributes to increase the level of job satisfaction ( $\beta=$ $0.14 *$, significant at $\rho \leq 0.05$ ). These findings are identical with the work of
Alexander and Ruderman (1987) and Yoon (1996) who pointed out that both distributive and procedural justice can explain level of satisfaction. Nevertheless, to some extent procedural justice might be more important than distributive justice in explaining job satisfaction. For example, Yoon's (1996) study found both procedural justice and distributive justice have effect on job satisfaction but the effect of procedural justice is greater that of distributive justice. It is because individuals may have great respect for group membership for its own sake and more emphasize on whether they receive an equitable decision-making procedure rather than the content of reward (Yoon 1996).

As hypothesized in the earlier section (Hypothesis 3), the model demonstrated that job satisfaction has a positive direct influence on affective commitment. The finding demonstrates consistent result with empirical evidence of the previous research (e.g., DeCotiis and Summers 1987; Meyer, Allen and Smith 1993; Wanous et al. 1992). The result means that employees who feel satisfied with their job will remain 'affective committed' to the organization, as long as the exchange relationship is satisfactory. Perceived job satisfaction, as consequence of the existing job circumstances, can influence employees' affective commitment. Affective commitment as an emotional attachment may develop on the basis of psychologically rewarding experiences (i.e., contents and procedures how the re- 
Rifai-A Test of the Relationships among Perceptions of Justice, Job Satisfaction, ...

ward are established). Therefore, an individual experiences positive emotional states, or happy with their job, will show a stronger emotional attachment to the organization.

Test of hypothesis 4 found that affective commitment has a positive direct effect on OCB. The part of the model is consistent with previous empirical evidence (Bolon 1997; O'Reilly and Chatman 1986; Organ 1990; Organ and Ryan 1995; Shore and Wayne 1993). It means that employees with strong affective commitment will demonstrate a higher extra-role behavior (OCB). The basic concept of OCB is to what extent the employees' extra role behavior, which is not directly linked to formal reward system, support the efficient and effective functions of organization, as the behavior is reflected in employees' cooperatives, spontaneous, and innovative response to the organization (Organ 1988). The model denoted that affective commitment, which characterized by employees' emotional attachment to, identification with, and involvement in the organization drives individuals to demonstrate citizenship behavior.

Meyer and Allen (1991) noted that employees with strong affective commitment are more likely to make a high effort on behalf of the organization than normative or continuance commitment. Employees with strong affective commitment show a higher willingness to contribute to achieve organizational effectiveness by helping others with organizationally rel- evant task. Their psychological attachment may stimulate an increase desire for affiliation without direct links to reward system. Affective commitment is more related to the social exchange concept rather than an economics exchange. The link between affective commitment and OCB is that individuals' positive behavior in the workplace is not directly related to their reward and individuals' effort to improve the organizational effectiveness are beyond their job description. Meanwhile, a job description is a reflection of a psychological contract between the employee and the organization. This psychological contract indicates the beliefs of the parties involved in an exchange relationship, regarding their reciprocal obligations. Unlike the psychological contract, which requires obligation to repay, the nature of OCB is based on voluntaryness which is characterized by the nature of innovative and spontaneous to achieve organization objective.

\section{Implications and Limitations}

The research provides several implications for improvement of our understanding of the relationship among work-related perceptions (i.e., justice perceptions), attitudes (i.e., job satisfaction and affective commitment) and behavioral outcomes (i.e., OCB) in the Asian context's, especially in Indonesia. First, researchers studying organizational citizenship behavior in the health care industry in Indonesia might be focused on perceived justice, 
Gadjah Mada International Journal of Business, May-August 2005, Vol. 7, No. 2

job satisfaction, and affective commitment as its antecedents. Organizational citizenship behavior can be view as a sequential process which forms the workers' behavior to behave spontaneously beyond their job description in order to maintain organization's effectiveness. The results advocate that the organization is preferable to build OCB by concerning in justice perceptions, job satisfaction, and affective commitment.

Second, the findings demonstrate the importance of understanding the consequences of perceived fairness by individuals in the health care industry (i.e., hospitals and clinics) and that the effect of procedural justice and distributive justice on peoples' attitudes might be different. Managers must be aware that the impact of perceptions of justice in managing rewards, which include the contents and the processes, does not only directly enhance job satisfaction but also can indirectly strengthen affective commitment. Perception of justice can be improved in several ways, such as conducting survey which will involve employees in determining processes related to benefit decisions, providing flexibility in selecting their needs-benefit packages, providing adequate information on how compensation is determined and managing employee's complaint in a well and timely manner. Furthermore, procedural justice may serve to minimize employees' reaction to perceived unequal outcome (e.g., pay raise).

Third, from the theoretical perspective the study found additional evidence that organizational justice affect job satisfaction, and job satisfaction appears to affect OCB. Organization can increase the degree of employees' OCB by means of developing affective commitment. Nevertheless, to develop affective commitment takes time longer than developing job satisfaction. Alternatively, in the meantime, organization can also directly control job satisfaction through improving perceived of fairness. Job satisfaction, as an attitude, can be increased as consequence of the social interaction between individuals and situations that include the functions of perceptions of justice.

The potential implications of this study also can be viewed from the strategic perspective of an organization. Internal adaptability of organization is deemed as an important precursor to adapting to external environmental change (Ostroff 1992). In keeping with the concept of citizenship behavior, OCB reflects a mechanism for internal adaptability of an organization, in which behavior is discretionary, not directly or explicitly recognized by the formal reward system and the aggregate promotes the efficient and effective functioning of organization (Organ 1988). In other words, that mechanism to adapt external environmental changes requires organizational members to behave above and beyond the job requirement as well as their formal job descriptions. OCB has been seen as having beneficial organizational impacts in the long-term, primarily in the service 
Rifai-A Test of the Relationships among Perceptions of Justice, Job Satisfaction, ...

industry (e.g., hospitals). As Netemeyer et al. (1997) said, 'organization with internal environments that foster OCBs might be able to adapt to external environmental changes more fluidly (p. 95).

Although the study has reviewed fairly comprehensive body of literature, clearly, all research has limitation that provide an indication of the future research. First, the study tested the model which reflected causal-effect relation among its variables, and it was examined simultaneously against its dependent variables by using cross sectional data. However, the causaleffect relationship becomes increasingly apparent when established using longitudinal data. Thus, future research is suggested to utilize longitudinal design with appropriate time lag, mainly with respect to studies with actual turnover as dependent variable. Second, the data collection of this study relied on self-reports. All variables in the study were measured from the same respondents and attempts were made to interpret their correlational nature. Because the measures come from the same source, common method variance problem could emerge to affect correlation among variables. In an effort to minimizethis problem, the scales in the survey instruments were reordered so that the dependent variables follow the independent variables rather than precede them (Podsakoff and Organ 1986). Furthermore, results of principal factor analysis noted that the indicator variables fit with unobserved constructs which they are purported to measure. Therefore, common methods variance is unlikely to confound the explanation of the findings. However, it is recommended that this study be replicated in order to establish the validity of the findings. Finally, this study is designed to investigate factors that influence OCB. Although perhaps many other factors influence that, the study has limited analysis to several factors which were identified from literature. These are: procedural justice, distributive justice, job satisfaction, and affective commitment. It is expected that the future studies to consider additional factors beyond those variables.

\section{Conclusion}

The tests of theoretical model of the research using AMOS software indicated that the model have met goodness-of-fit criteria, thus, the interpretation of the model was fit with the data. The major findings in this study are that (a) both procedural and distributive justice have a positive effect to job satisfaction, (b) job satisfaction has a positive and strong effect on affective commitment, and (c) affective commitment has a direct effect to OCB.

The results of structural equation modeling analysis suggested that organization might increase citizenship behavior by means of strengthen employees' affective commitment. The findings exemplified that affective commitment is significantly preceded by job satisfaction. The empirical evi- 
Gadjah Mada International Journal of Business, May-August 2005, Vol. 7, No. 2

dence also pointed out that both procedural justice and distributive justice have an important effect to improve job satisfaction. Finally this study provides significant contribution to support the argument that there is a direct impact of affective commitment on OCB when the job satisfaction is considered as an antecedent of affective commitment. It can be concluded that enhancement of job satisfaction of workers will lead to a higher level of
OCB through the effect of affective commitment. Therefore, this study represents guidelines to help managers understanding how to increase organizational citizenship behavior by identifying its antecedents. In sum, citizenship behavior process might be portrayed as psychological stages which are affected by perception of justice, job satisfaction, and affective commitment, respectively.

\section{References}

Adam, JS 1965, 'Injustice in social exchange', in L Berkowitz (ed.), Advances in experimental social psychology, Academic Press, New York London, pp. 267-99.

Agho, A.O., C. W. Mueller, and J.L. Price. 1993. Determinants of employee job satisfaction: An empirical test of a causal model. Human Relations 46 (8): 1007-27.

Alexander, S., and M. Ruderman. 1987. The role of procedural and distributive justice in organizational behavior. Social Justice Research 1: 177-98.

Allen, N. J., and J. P. Meyer. 1990. The measurement and antecedents of affective, continuance and normative commitment to the organization. Journal of Occupational Psychology 63 (1): 1-18.

Angle, H. L., and J. L. Perry. 1981. An empirical assessment of organizational commitment and organizational effectiveness. Administrative Science Quarterly 26 (1): 1-14.

Begley, T. M., and J. M. Czajka. 1993. Panel analysis of the moderating effects of commitment on job satisfaction, intent to quit, and health following organizational change. Journal of Applied Psychology 78 (4): 552-56.

Bollen, K., and R. Lennox. 1991. Conventional wisdom on measurement: A structural equation perspective. Psychological Bulletin 110 (2): 305-14.

Bolon, D.S. 1997. Organizational citizenship behavior among hospital employees: A multidimensional analysis involving job satisfaction and organizational commitment. Hospital and Health Services Administration 42 (2): 221-41.

Brayfield, A. H., and H. F. Rothe. 1951. An index of job satisfaction. Journal of Applied Psychology 35 (5): 307-11.

Byrne, B. M. 2001. Structural Equation Modeling with AMOS: Basic Concepts, Applications, and Programming. Mahwah, N.J.: Multivariate applications book series, Lawrence Erlbaum Associates. 
Rifai-A Test of the Relationships among Perceptions of Justice, Job Satisfaction, ...

Cropanzano, R., and J. Greenberg. 1997. Progress in organizational justice: Tunneling through the maze. In C. Cooper and I. Roberstson (eds), International Review of Industrial and Organizational Psychology (12): 317-372. New York: John Wiley and Sons.

DeCotiis, T. A., and T. P. Summers. 1987. A path analysis of a model of the antecedents and consequences of organizational commitment. Human Relations 40 (7): 445-70.

Deutsch, R. E. 1985. Tomorrow's work force: New values in the workplace. The Futurist 19 (6): 8-11.

Dyne, L. V ., and S. Ang. 1998. Organizational citizenship behavior of contingent workers in Singapore. Academy of Management Journal 41 (6): 692-703.

Fields, D., M. Pang, and C. Chiu. 2000. Distributive and procedural justice as predictors of employee outcomes in Hong Kong. Journal of Organizational Behavior 21 (5): 547-62.

Folger, R. and M.A. Konovsky. 1989. Effects of procedural and distributive justice on reactions. Academy of Management Journal (32) 1: 115-30.

Folger, R., and C. L. Martin. 1989. Relative deprivation and referent cognition: Distributive and procedural justice effect. Journal of Experimental and Social Psychology 22: 531-46.

Folger, R., and R. Cropanzano. 1998. Organizational Justice and Human Resource Management. Thousand Oaks: Foundations for organizational science, Sage Publications.

Greenberg, J. 1987. A Taxonomy of organizational justice theories. Academy of Management. The Academy of Management Review 12 (1): 9-22.

1990. Organizational justice: Yesterday, today, and tomorrow. Journal of Management 16 (2): 399-432.

1996, The quest for justice on the job : essays and experiments, Sage Publications, Thousand Oaks, Calif.

Hair, J. R., R. E. Anderson, R. L. Tatham, and W. C. Black. 1998. Multivariate Data Analysis ( $5^{\text {th }}$ ed.). Upper Saddle River, New Jersey: Prentice-Hall, Inc.

Homans, G. C. 1961. Social Behavior : Its Elementary Forms. New York: Harcourt Brace and World.

Igalens, J., and P. Roussel. 1999. A study of the relationships between compensation package, work motivation and job satisfaction. Journal of Organizational Behavior 20 (7): 1003-25.

Jasso, G. 1980. A new theory of distributive justice. American Sociology Review 45: 332.

Konovsky, M. A., and S. D. Pugh. 1994. Citizenship behavior and social exchange. Academy of Management Journal 37 (3) 656-69.

Lawler, E. E. 1971. Pay and Organizational Effectiveness: A Psychological View. New York: McGraw-Hill series in psychology, McGraw-Hill. 
Gadjah Mada International Journal of Business, May-August 2005, Vol. 7, No. 2

Lind, E. A., and T. R. Tyler. 1988. The social psychology of procedural justice. Critical issues in Social Justice. New York: Plenum Press.

Lum, L., J. Kervin, K. Clark, R. Frank, and W. Sirola. 1998. Explaining nursing turnover intent: Job satisfaction, pay satisfaction, or organizational commitment? Journal of Organizational Behavior 19: 305-20.

Martin, C. L., and N. Bennett. 1996. The role of justice judgments in explaining the relationship between job satisfaction and organization commitment. Group and Organization Management 21 (1): 84-104.

Martin, J. 1981. Relative deprivation: A theory of distributive justice for an era of shrinking resources. In CL. L., and B. M. Staw (eds), Research in Organizational Behavior 3: 53-108. CT, Greenwich: JAI Press.

Mathieu, J. E., and D. M. Zajac. 1990. A review and meta-analysis of the antecedents, correlates, and consequences of organizational commitment. Psychological Bulletin 108 (2): 171-94.

McFarlin, D. B., and P. D. Sweeney. 1992. Distributive and procedural justice as predictors of satisfaction with personal and organizational outcomes. Academy of Management Journal 35 (3): 626.

Meyer, J. P., and N. J. Allen. 1984. Testing the "Side-Bet Theory" of organizational commitment: Some methodological considerations. Journal of Applied Psychology 69 (3): 372-78.

. 1987. A longitudinal analysis of the early development and consequences of organizational commitment. Canadian Journal of Behavioral Science 19: 199215.

1991. A three-component conceptualization of organizational commitment. Human Resources Management Review 1 (1): 61-89.

Meyer, J. P., N. J. Allen, and C. A. Smith. 1993. Commitment to organizations and occupations: Extension and test of a three-component conceptualization. Journal of Applied Psychology 78 (4): 538-51.

Meyer, J. P., D. J. Stanley, L. Hersecovith, and L. Topolnytsky. 2000. Affective, continuance, and normative commitment to the organization: A meta-analysis of antecedents, correlates, and consequences. Journal of Vocational Behavior 61: 2052.

Morrison, E. W. 1994. Role definitions and organizational citizenship behavior: The importance of the employee's perspective. Academy of Management Journal 37: 1543-67.

Mowday, R. T., R. M. Steers, and L. W. Porter. 1979. The measurement of organizational commitment. Journal of Vocational Behavior 14: 224-47.

Mowday, R. T, L. W. Porter, and R. M. Steers. 1982. Employee-organization linkages: The psychology of commitment, absenteeism, and turnover. Organizational and Occupational Psychology. New York: Academic Press. 
Rifai-A Test of the Relationships among Perceptions of Justice, Job Satisfaction, ...

Netemeyer, R. G., J. S. Boles, D. O. McKee, and R. McMurrian. 1997. An investigation into the antecedents of organizational citizenship behaviors in a personal selling context. Journal of Marketing 61 (3): 85-98.

O'Reilly, C. A., and J. Chatman. 1986. Organizational commitment and psychological attachment: The effects of compliance, identification, and internalization on prosocial behavior. Journal of Applied Psychology 71 (3): 492-9.

Organ, D. W. 1987. The Applied Psychology of Work Behavior : A Book of Readings $\left(3^{\text {rd }}\right.$ ed.). Plano, Tex: Business Publications.

. 1988. Organizational citizenship behavior : The good soldier syndrome. Issues in Organization and Management Series. Lexington, Mass.: Lexington Books.

. 1990. The motivational basis of organizational citizenship behavior. Research in Organizational Behavior 12 (4): 43-72.

Organ, D. W., and K. Ryan. 1995. A meta-analytic review of attitudinal and dispositional predictors of organizational citizenship behavior. Personnel Psychology 48 (4): 775-802.

Ostroff, C. 1992. The relationship between satisfaction, attitude, and performance: An organizational level analysis. Journal of Applied Psychology 6 (77): 963-74.

Podsakoff, P. M., and D. W. Organ. 1986. Self-reports in organizational research: Problems and prospects. Journal of Management 12 (4): 531-44.

Porter, L. W., R. M. Steers, R. T. Mowday, and P. V. Boulian. 1974. Organizational commitment, job satisfaction, and turnover among psychiatric technicians. Journal of Applied Psychology 59: 603-9.

Price, J. L., and C. W. Mueller. 1986. Absenteeism and turnover of hospital employees. Monographs in Organizational Behavior and Industrial Relations. Greenwich, Conn.: JAI Press.

Scarpello, V., and F. F. Jones. 1996. Why justice matters in compensation decision making. Journal of Organizational Behavior 17 (3): 285-99.

Schappe, S. P. 1998. The influence of job satisfaction, organizational commitment, and fairness perceptions on organizational citizenship behavior. The Journal of Psychology 132 (3): 277-90.

Shore, L. M., and S. J. Wayne. 1993. Commitment and employee behavior: Comparison of affective c. Journal of Applied Psychology 78 (5): 774-80.

Smith, C. A., D. W. Organ, and J. P. Near. 1983. Organizational citizenship behavior: Its nature and antecedents. Journal of Applied Psychology 68 (4): 653-63.

Sweeney, P. D., and D. B. McFarlin. 1997. Process and outcome: Gender differences in the assessment of justice. Journal of Organizational Behavior 18 (1): 83-98.

Tabachnick, B. G., and L. S. Fidell. 2001. Using Multivariate Statistics (4 ${ }^{\text {th }}$ edn.). Boston, Mass.: Allyn and Bacon.

Tremblay, M, B. Sire, and D. B. Balkin. 2000. The role of organizational justice in pay and employee benefit satisfaction, and its effects on work attitudes. Group and Organization Management 25 (3): 269-90. 
Gadjah Mada International Journal of Business, May-August 2005, Vol. 7, No. 2

Tyler, T. R., K. Rasinki, and K. McGraw. 1985. The influence of perceived injustice on the endorsement of political leaders. Journal of Applied Psychology 15: 700-25.

Wanous, J. P., T. D. Poland, and S. L. Premack, and K. S. Davis. 1992. The effects of met expectations on newcomer attitudes and behaviors: A review and meta-analysis. Journal of Applied Psychology 77 (3): 288-97.

Wiener, Y. 1982. Commitment in organizations: A normative wiew. Academy of Management. The Academy of Management Review 7 (3): 418-28.

Williams, L. J., and J. T. Hazer. 1986. Antecedents and consequences of satisfaction and commitment in turnover models: A reanalysis using latent variable structural equation methods. Journal of Applied Psychology 71 (2): 219-31.

Williams, L. J., and S. E. Anderson. 1991. Job satisfaction and organizational commitment as predictors of organizational citizenship and in-role behaviors. Journal of Management 17: 601-17.

Yoon, J. 1996. Fairness issues and job satisfaction among Korean employees: The significance of status value and procedural justice in work orientation. Social Justice Research (9) 2: 121-43.

Yoon, J., and S. R. Thye. 2002. A dual process model of organizational commitment: Job satisfaction and organizational support. Work and Occupations 29 (1): 97-124. 